\title{
Petrographic and geochemical study of the Maastrichtian Ajali Sandstone, North Central Nigeria
}

\author{
Jude Etunimonuwa OGALA ${ }^{1, *}$, Samuel Bamidele OLOBANIYI', \\ Omolemo Olutoyin OMO-IRABOR ${ }^{3}$ and Edwin Ozor ADAIKPOH ${ }^{1}$ \\ 1 Delta State University, Department of Geology, P.M.B. 1, Abraka, Nigeria \\ 2 University of Lagos, Department of Geosciences, Lagos, Akoka, Nigeria \\ 3 Federal University of Petroleum Resources, Department of Earth Sciences, P.M.B. 1221, Effurun, Nigeria
}

Ogala, J.E., Olobaniyi, S.B., Omo-Irabor, O.O., Adaikpoh, E.O., 2015. Petrographic and geochemical study of the Maastrichtian Ajali Sandstone, North Central Nigeria. Geological Quarterly, 59 (1): 79-90, doi: 10.7306/gq.1208

\begin{abstract}
The Upper Cretaceous Ajali Sandstone is an extensive stratigraphic unit of the Anambra Basin in southern Nigeria. It consists of friable, white cross-bedded sandstones exhibiting a fining upward sequence. Structures such as bioturbation, planar and herringbone cross beds indicate variability in depositional environment ranging from fluviatile to deltaic. Petrographic and geochemical compositions (major and trace elements) of these sandstones have been investigated to determine their provenance, tectonic setting and weathering conditions. Fifteen sandstone samples examined are rich in quartz but poor in feldspar and lithic fragments. Texturally, the framework grains of the sandstones are fine- to medium-grained, sub-angular to sub-rounded, moderately sorted to poorly sorted, positively skewed and leptokurtic. The sandstones are texturally immature as depicted by their sub-angular edges of grains, but mineralogically mature in terms of high percentage of quartz. The high chemical index of alteration ( $\mathrm{CIA}$ ) values (71.0-99.2\%) for these sandstones suggests that they were derived from highly weathered rocks in the source area. The composition of the major oxides in the sandstones revealed that $\mathrm{SiO}_{2}(49.1-99.7 \%)$, $\mathrm{Al}_{2} \mathrm{O}_{3}(0.2-30.3 \%), \mathrm{Fe}_{2} \mathrm{O}_{3}(0.4-1.8 \%)$ and $\mathrm{TiO}_{2}(0.06-3.2 \%)$ were the most abundant elements in all sandstone samples indicating a high detrital quartz and clay mineral content. The $\mathrm{Al}_{2} \mathrm{O}_{3} / \mathrm{TiO}$ ratios (1.47 to 12.48$), \mathrm{Ti} / \mathrm{Zr}(6.48-18.63)$ and $\mathrm{Zr} / \mathrm{Cr}$ (2.24-22.36) suggest that the sandstones were derived from variable basement complex rocks, including some contribution from mafic or ultramafic components. Inferences from the plots of $\mathrm{K}_{2} \mathrm{O} / \mathrm{Na}_{2} \mathrm{O}$ versus $\mathrm{SiO}_{2}$ indicated a passive margin tectonic setting for the sandstones. The high loading of $\mathrm{CaO}$ and $\mathrm{Na}_{2} \mathrm{O}$ in more than $50 \%$ of the samples is indicative of terrigenous input, mainly in the form of carbonates and silicates. These results are generally consistent with a derivation of the sandstones from adjacent igneous and metamorphic basement complexes (Cameroon-Adamawa highlands and Oban Massif) while the extensive and blanket-like geometry of the Ajali Sandstone is indicative of an excellent reservoir for groundwater in the Anambra Basin.
\end{abstract}

Key words: petrography, geochemistry, Ajali Sandstone, provenance, tectonic setting, Nigeria.

\section{INTRODUCTION}

The Maastrichtian Ajali Sandstone (Reyment, 1965) extends from Fugar/Agenebode area in the west along the Udi Hill in the east, and thins south-east of Okigwe in Nigeria (Hoque and Ezepue, 1977; Tijani et al., 2010) thereby forming an overall blanket-like geometry (Ladipo, 1986). It is an extensive stratigraphic unit of the Anambra Basin with a maximum thickness of 500 to 600 metres in the central part of the basin (Simpson, 1954). It thins to the south (Simpson, 1954) to about 200 metres where its outcrop crosses the axis of the Abakaliki Anticlinorium, though only a few tens of metres were reported from this area by Ladipo (1986). This formation is exposed on the Awgu-Enugu Escarpment and Udi Hill (Fig. 1).

* Corresponding author, e-mail: etunimogala@yahoo.com

Received: Received: March 9, 2014; accepted: November 26, 2014; first published online: December 29, 2014
Murat (1972) described the stratigraphy and palaeogeography of the Cretaceous and Paleogene in the Southern Nigeria sedimentary basin in terms of three major tectonic phases which controlled the morphology and evolution of the basin (Fig. 2). According to Burke et al. (1972), the Santonian uplift resulted in the erosion of over $2000 \mathrm{~m}$ of sediments from the Abakaliki folded belts and much of these eroded materials were deposited in the Anambra Basin, which became the major depocenter during Campanian to Early Eocene time.

Hoque (1977) studied the petrographic characteristics of sandstone units in southeastern Nigeria, deposited during the first and second tectonic episodes of Murat (1972). He used the petrographic characteristics of sandstone units as evidence of a major change in the tectonic events in the area, in recognizing the stratigraphic boundary between two sedimentary cycles, and delineating margins of pre-Santonian and post-Santonian basins. Hoque and Ezepue (1977) studied the petrology and palaeogeography of the Ajali Sandstone and reported that intense chemical weathering under humid condition both at source and during transportation could eliminate feldspars and 


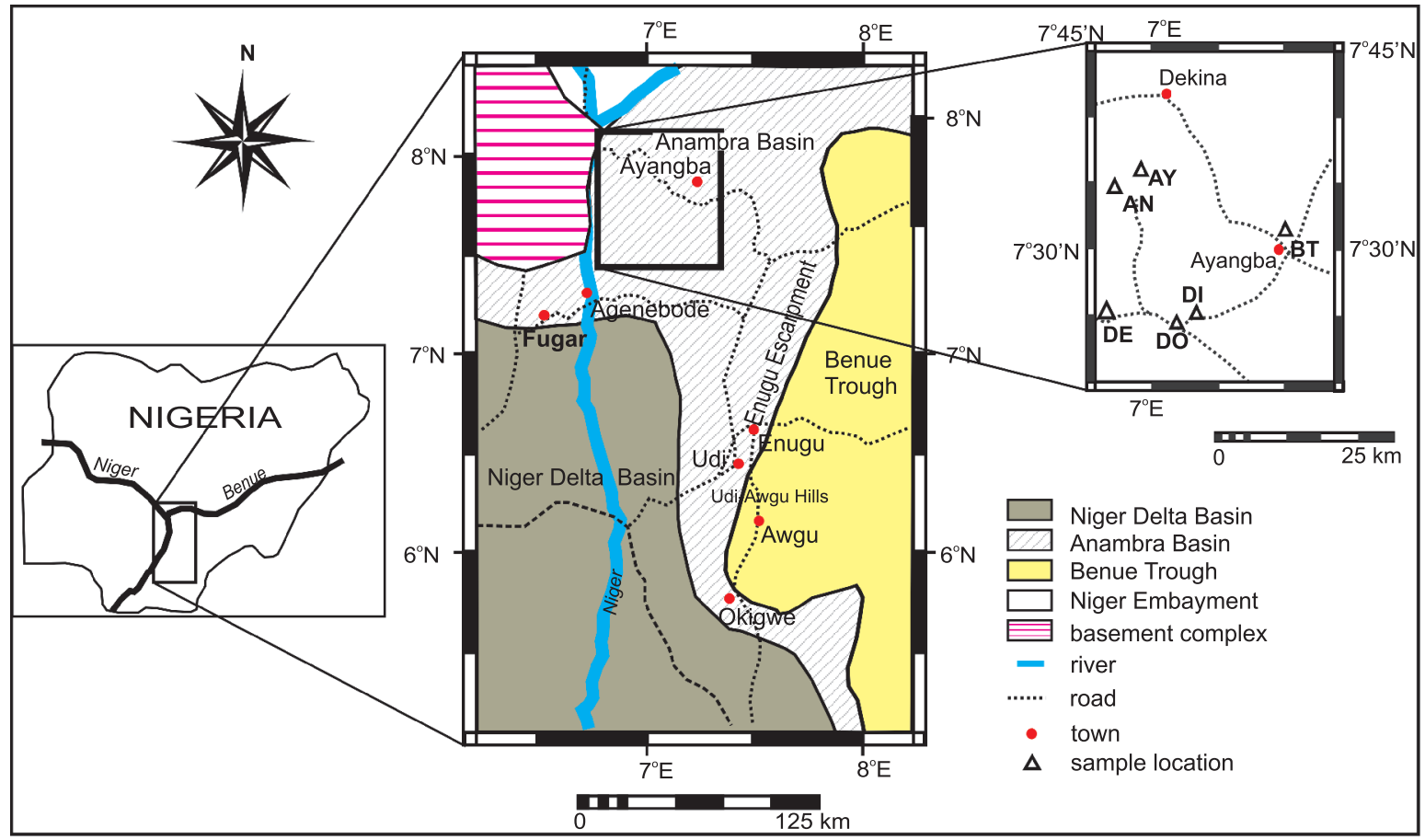

Fig. 1. Map of the study area showing sampling locations

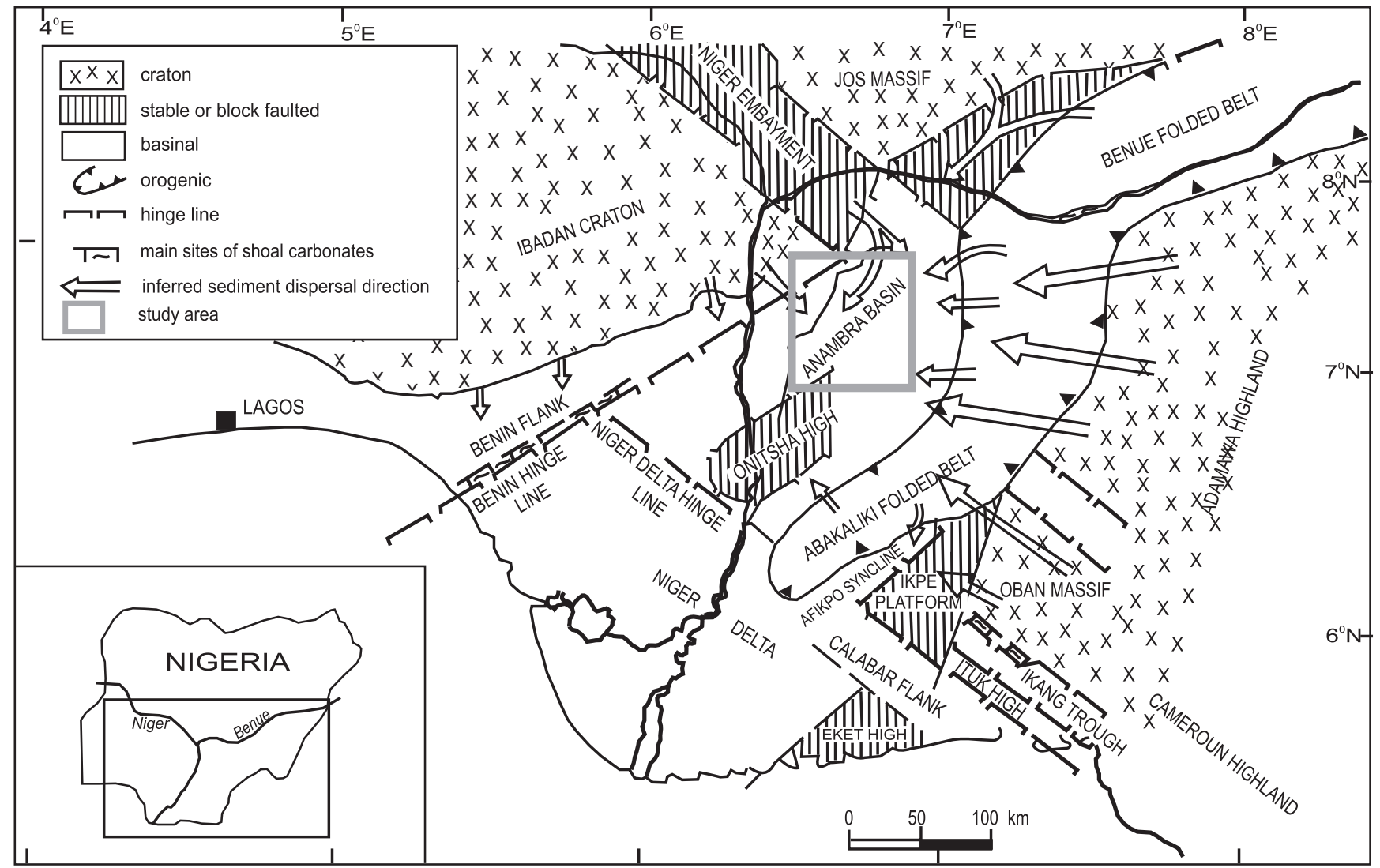

Fig. 2. Palaeogeographic map of the Anambra Basin during the Maastrichtian-Danian (modified from Murat, 1972) 
other labile fractions to produce mineralogically mature sand. Such a deposit is unlikely to have textural maturity of quartz arenites deposited on a stable platform. The mineralogically mature Ajali Sandstone, as well as sandstone units of the Enugu, Mamu, Nsukka and Nanka formations of the second phase were formed by profound chemical weathering of granitic rocks of the Cameroon highlands in a climatic environment very similar to the present-day humid condition. Hoque and Ezepue (1977) also interpreted the Ajali Sandstone as a fluvio-deltaic deposit and suggested a derivation from the Cameroon-Adamawa highlands. Tijani et al. (2010) studied the textural and geochemical characteristics of the Ajali Sandstone and noted that the source area is constrained to the Precambrian basement rock units of Adamawa-Oban Massif areas to the east of the Anambra Basin and the adjacent Abakaliki Anticlinorium.

Banerjee (1979), Amajor (1984) and Ladipo (1986, 1988) described a number of features indicative of a tidal to shallow sub-littoral palaeoenvironment: Ophiomorpha and Skolithos; bipolar-bimodal current azimuths; and reactivation surfaces of inferred tidal origin. Ladipo (1986) suggested a sub-tidal to tidal origin for the Ajali Sandstone with a gradation into more paralic deposits in the sub-surface.

The sandstone beds occurring in Ayangba and environs are the western extension of the post-Santonian Ajali Sandstone of the Anambra Basin (Fig. 1). Much as the lithostratigraphic units of the Anambra Basin are well-known and documented (Tattam, 1944; Simpson, 1947, 1954; Reyment, 1965; Murat, 1972; Hoque and Ezepue, 1977; Ladipo, 1986, 1988), little attention has been paid to the extension of the Maastrichtian Ajali Sandstone in the Ayangba locality. This study assesses the petrographic and geochemical compositions of Ajali Sandstone outcrops in Ayangba and its environs in order to infer their provenance, tectonic setting of the source area and weathering conditions in the source area.

\section{LOCATION OF STUDY AREA AND GEOLOGY}

Ayangba is located in north-central Nigeria within latitudes $7^{\circ} 20^{\prime}$ and $7^{\circ} 45^{\prime} \mathrm{N}$, and longitudes $6^{\circ} 45^{\prime}$ and $7^{\circ} 15^{\prime} \mathrm{E}$ (Fig. 1). This area is underlain by the Ajali Sandstone Formation that occasionally form prominent topographic features. Regionally, the Ajali Sandstone is underlain by the Mamu Formation and overlain by the Nsukka Formation (Fig. 3 and Table 1).

The origin and evolution of the sedimentary basins (BenueAbakaliki folded belts, Niger Embayment, Anambra Basin, Afikpo Syncline and Niger Delta; Fig. 2) in Southern Nigeria is associated with the opening of the South Atlantic Ocean during Early Cretaceous time (Murat, 1972; Nwachukwu, 1972). Sedimentation in the southern Nigerian basins began during the Early Cretaceous (Albian) following the basement subsidence along the Benue Trough (Nwachukwu, 1972; Olade, 1975; Fig. 1). Folding and uplift occurred during the Santonian along a NE-SW axis in the Abakaliki-Benue folded belts (Fig. 2). The Anambra Platform, lying to the west and south-west of the Abakaliki folded belts, subsided to form the Anambra Basin (Reyment, 1965; Short and Stauble, 1967; Murat, 1972; Benkhelil, 1989; Fig. 1).

The post-Santonian stratigraphic succession in the Anambra Basin began with the deposition of the marine CampanianMaastrichtian Enugu/Nkporo Shales and its lateral equivalent the deltaic Owelli Sandstone (Table 1). These basal units are overlain successively by the Lower-Middle Maastrichtian deltaic coal-bearing Mamu Formation (Lower Coal Measures), Middle Maastrichtian tidal Ajali Sandstone (False-Bedded Sandstones) and the fluvial-deltaic Nsukka Formation (Upper Coal Measures; Table 1).

The Ajali Sandstone in the Anambra Basin, which is the focus of this study consists of friable, white cross-bedded sand-

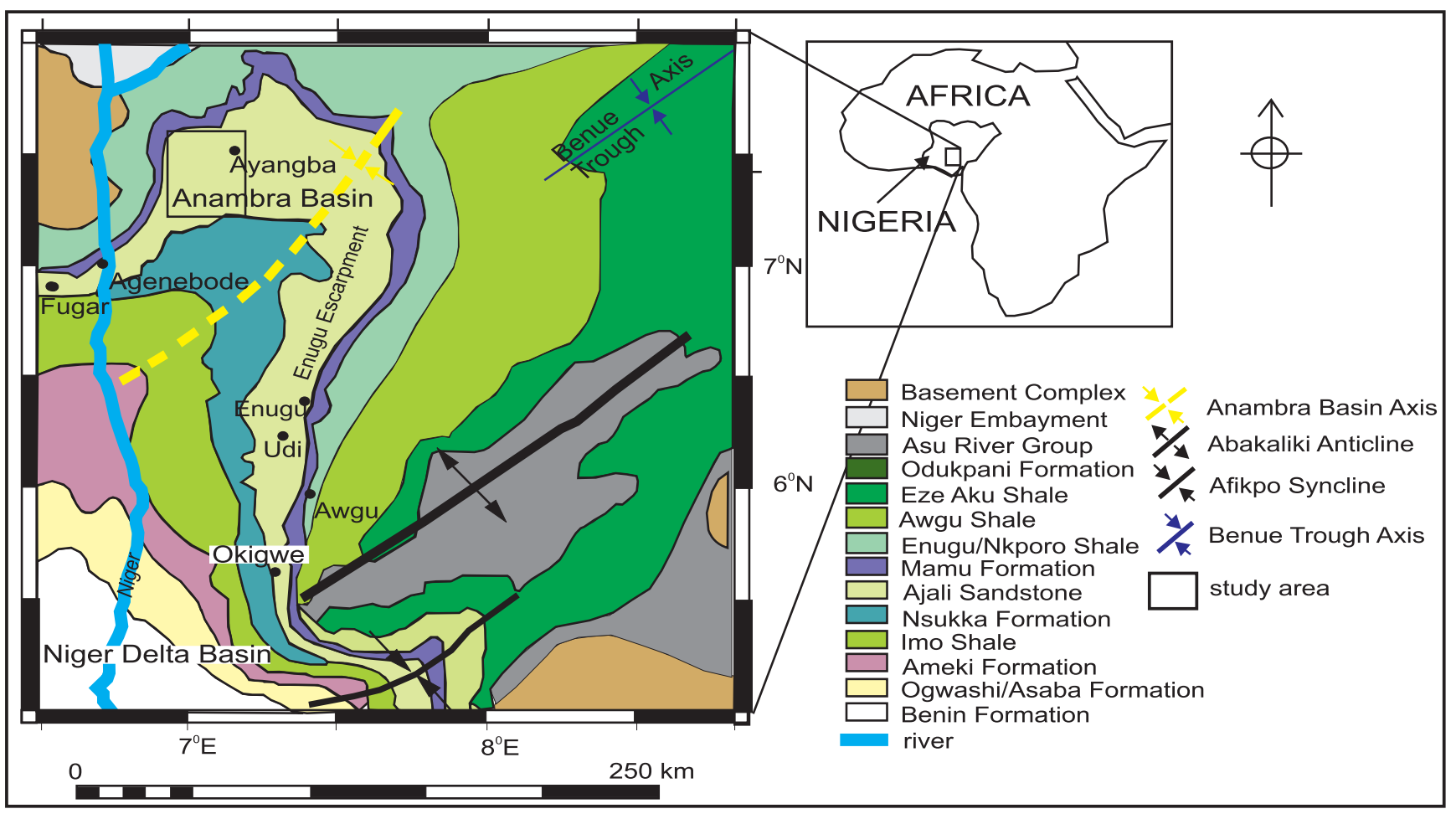

Fig. 3. Geological map showing the Anambra Basin and the adjacent units in southern Nigeria (inset: map of Nigeria showing the location of study area; modified from Akande et al., 2007) 
Table 1

Stratigraphic subdivision of the southern Benue Trough (modified from Reyment, 1965)

\begin{tabular}{|c|c|c|c|c|c|c|}
\hline ERA & \multicolumn{2}{|c|}{ PERIOD/AGE } & FORMATION & LITHOLOGY & $\begin{array}{l}\text { DEPOSITIONAL } \\
\text { ENVIRONMENT }\end{array}$ & BASIN \\
\hline \multirow{6}{*}{$\begin{array}{l}.0 \\
\text { N } \\
O \\
\frac{O}{0} \\
0\end{array}$} & \multicolumn{2}{|r|}{ Quaternary } & \multirow[b]{2}{*}{ Benin Formation } & \multirow[b]{2}{*}{$\begin{array}{l}\text { sandstones, clays, } \\
\text { shales }\end{array}$} & \multirow[b]{2}{*}{ continental } & \multirow{6}{*}{ 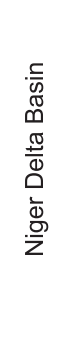 } \\
\hline & 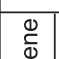 & Pliocene & & & & \\
\hline & ¿ & Miocene & \multirow{2}{*}{ Ogwashi Asaba Formation } & \multirow{2}{*}{$\begin{array}{c}\text { clays, shales, sandstones, } \\
\text { lignites }\end{array}$} & \multirow[b]{2}{*}{ continental } & \\
\hline & \multirow{3}{*}{$\begin{array}{l}0 \\
\frac{0}{0} \\
\delta \\
\delta \\
\frac{0}{\sigma} \\
0\end{array}$} & Oligocene & & & & \\
\hline & & Eocene & $\begin{array}{c}\text { Ameki Formation/ } \\
\text { Nanka Sand }\end{array}$ & $\begin{array}{l}\text { sandstones, clays, } \\
\text { shales, limestones }\end{array}$ & $\begin{array}{c}\text { estuarine, } \\
\text { shallow marine }\end{array}$ & \\
\hline & & Paleocene & Imo Formation & $\begin{array}{c}\text { clays, shales, limestone, } \\
\text { sandstones, marls }\end{array}$ & $\begin{array}{c}\text { shallow marine, } \\
\text { deltaic }\end{array}$ & \\
\hline \multirow{10}{*}{$\begin{array}{l}0.0 \\
\text { N } \\
0 \\
0 \\
\infty \\
\sum\end{array}$} & \multirow{9}{*}{$\begin{array}{l}0 \\
0 \\
0 \\
0 \\
0 \\
\frac{\pi}{0} \\
\frac{1}{0} \\
0 \\
\frac{1}{0} \\
\frac{0}{2} \\
\frac{0}{2}\end{array}$} & \multirow{3}{*}{ Maastrichtian } & Nsukka Formation & $\begin{array}{c}\text { sandstones, clays, } \\
\text { shales, coals, limestones }\end{array}$ & fluvio-deltaic & \multirow{5}{*}{ 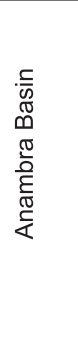 } \\
\hline & & & Ajali Sandstone & sandstones, claystones & fluvio-deltaic & \\
\hline & & & Mamu Formation & $\begin{array}{l}\text { sandstones, shales, } \\
\text { clays, coals }\end{array}$ & $\begin{array}{c}\text { shallow marine, } \\
\text { deltaic }\end{array}$ & \\
\hline & & \multirow[t]{2}{*}{ Campanian } & $\begin{array}{c}\text { Enugu/Nkporo/Owelli } \\
\text { Formation }\end{array}$ & $\begin{array}{c}\text { shales, sandstones, } \\
\text { clays, ironstones, } \\
\text { siltstones }\end{array}$ & $\begin{array}{l}\text { shallow marine, } \\
\text { deltaic }\end{array}$ & \\
\hline & & & \multicolumn{3}{|c|}{ MAJOR UNCONFORMITY } & \\
\hline & & Santonian & \multirow{2}{*}{ Awgu Formation } & \multirow{2}{*}{\begin{tabular}{|l|} 
sandstones, limestones, \\
clays, coals, siltstones
\end{tabular}} & \multirow{2}{*}{$\begin{array}{c}\text { shallow marine, } \\
\text { deltaic }\end{array}$} & \multirow{5}{*}{ 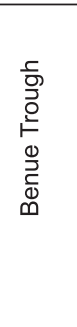 } \\
\hline & & Coniacian & & & & \\
\hline & & Turonian & Eze-Aku Formation & $\begin{array}{c}\text { shales, limestones, } \\
\text { sandstones }\end{array}$ & shallow marine & \\
\hline & & Cenomanian & Odukpani Formation & $\begin{array}{c}\text { sandstones, limestones, } \\
\text { shales }\end{array}$ & shallow marine & \\
\hline & 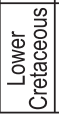 & Albian & Asu River Group & $\begin{array}{l}\text { shales, limestones, } \\
\text { sandstones }\end{array}$ & shallow marine & \\
\hline \multirow{2}{*}{\multicolumn{3}{|c|}{ Lower Paleozoic }} & \multicolumn{4}{|c|}{ MAJOR UNCONFORMITY } \\
\hline & & & basement complex & $\begin{array}{l}\text { granites, gneisses, } \\
\text { schists, migmatites }\end{array}$ & \multicolumn{2}{|c|}{ igneous, metamorphic } \\
\hline
\end{tabular}

stone with thin beds of whitish claystone. The cross-beds are large scale and dip about $20-30^{\circ}$ westwards. The sandstone units display thin, poorly defined cyclothems and contain abundant mud clasts. There are numerous bands of variegated, rarely carbonaceous shales and mudstones, often capping the sandstone cyclothems. The Ajali Sandstone is Maastrichtian in age with a thickness of about $500 \mathrm{~m}$ (Reyment, 1965) and often shows an upward-fining sequence. In the subsurface, the Ajali Sandstone is dominantly fine-grained and calcareous. It is usually shaly, and pyritic or carbonaceous, and may contain ostracods and arenaceous foraminifers (Agagu et al., 1985).

\section{SAMPLING AND METHODS}

\section{FIELD STUDY}

In this study, fifteen sandstone and two clay (lithified) samples were collected from six outcrops exposed at road cuts in the Ayangba area (Fig. 1). The spot sampling method, which mainly involves sampling of outcrops at designated locations, was used in the field for sampling. The samples collected were macroscopically examined. The mudstones were clay-sized (BT3) and silt-sized (DE1) samples. The grain-size of the sand- stone samples ranged from coarse to fine sand. There are sedimentary structures such as burrowing surfaces, and planar and herringbone cross beds (Figs. 4 and 5). The Ajali Sandstone consists of friable, white cross-bedded sandstone with thin beds of whitish claystone. The thicknesses of the studied sequences are 5-35 m (BT), 2-16 m (AY), 1-6 m (AN), 2-5 m (DO) and $0-5 \mathrm{~m}(\mathrm{DI})$. Figure 4 presents the lithological sections of the units studied.

\section{LABORATORY ANALYSIS}

The samples were disaggregated and subjected to grain-size analysis using a Ro-Tap automatic sieve shaker in order to determine particle size distribution in the sandstones. Graphic methods (Folk and Ward, 1957) were used in calculating the statistical grain-size parameters (mean grain-size, standard deviation, graphic skewness and kurtosis). For petrographic studies, thin sections of fifteen representative samples were examined with an optical microscope (ML 9000). Modal counts of 300 points were performed for each sample following the Gazzi-Dickinson point counting method (Gazzi, 1966; Dickinson, 1970).

Chemical analysis of fifteen representative sandstone and clay samples were performed at Activation Laboratory, Ontario, 


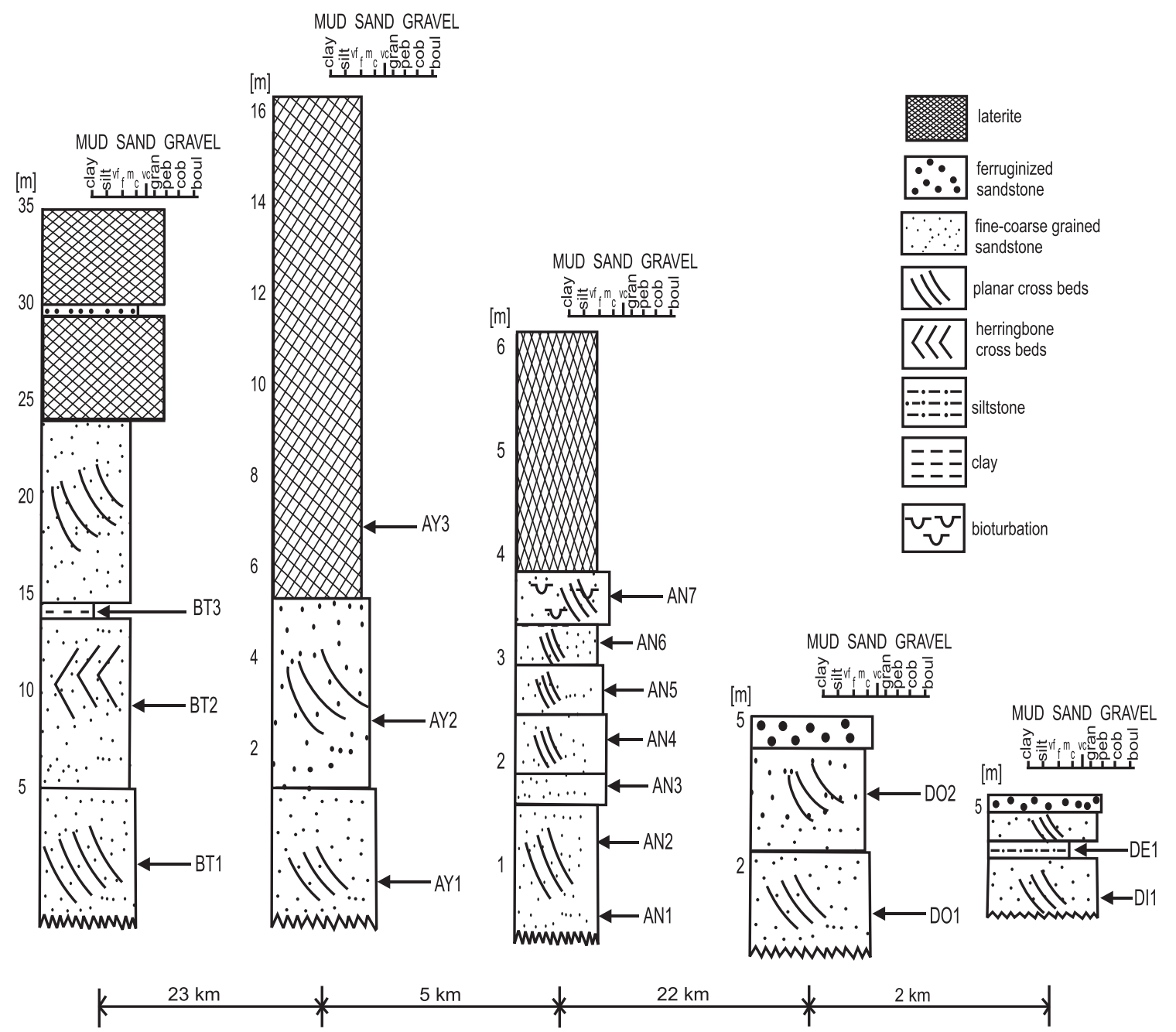

Fig. 4. Profiles of lithologic units showing distance between the measured sections

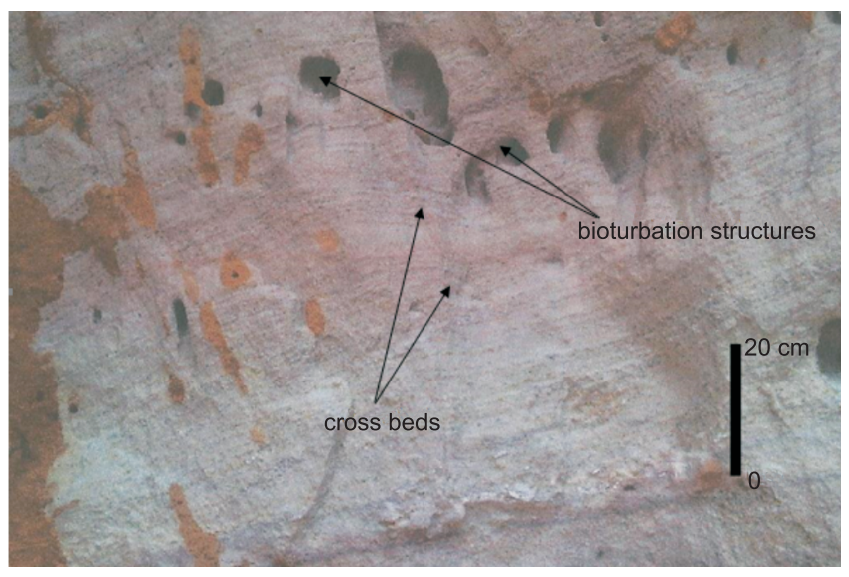

Fig. 5. Field photo of Ajali Sandstone outcrop showing bioturbation structures and cross beds

Canada, using inductively coupled plasma-optical emission spectrometry (ICP-OES) for determination of major and trace elements. Loss on ignition (LOI) was determined by weighing before and after ignition at $1050^{\circ} \mathrm{C}$. Limits of detectable measurement (LDM) for major elements were 0.01 for $\mathrm{SiO}_{2}, \mathrm{Al}_{2} \mathrm{O}_{3}$, $\mathrm{Fe}_{2} \mathrm{O}_{3}(\mathrm{~T}), \mathrm{MgO}, \mathrm{CaO}, \mathrm{Na}_{2} \mathrm{O}, \mathrm{K}_{2} \mathrm{O}$ and $\mathrm{P}_{2} \mathrm{O}_{5} ; 0.001$ for $\mathrm{MnO}$ and
$\mathrm{TiO}_{2}$ and $0.01 \%$ for S. LDM for trace elements were $2 \mathrm{ppm}$ for $\mathrm{Ba}, \mathrm{Sr}, \mathrm{Zr}, \mathrm{Bi}, \mathrm{Te} ; 1$ ppm for Y, Sc, Be, Co, Cr, Cu, Ga, Hg, Ni, Li, Mo, Ni and Zn; 5 ppm for $\mathrm{V}, \mathrm{Sb}, \mathrm{TI}$ and $\mathrm{W} ; 0.3 \mathrm{ppm}$ for $\mathrm{Ag}$ and $\mathrm{Cd} ; 10 \mathrm{ppm}$ for $\mathrm{U} ; 3 \mathrm{ppm}$ for As and $\mathrm{Pb}$ and $4 \mathrm{ppm}$ for Sc.

Statistical analyses were carried out using the statistical package for social sciences (SPSS version 20). Samples that have concentrations below the respective detection limit (Ag, As, Bi, Cd, Sb, S, TI, U and W) were excluded from further statistical treatment. Pearson's correlation coefficient was computed for the data set. Factor Analysis (FA) and Principal Component Analysis (PCA) were also applied on the data set standardized through z-scale transformation. Hierarchical agglomerative cluster analysis was performed on the data set by means of the Ward's method with a view to group the similar sampling sites spread over the region.

\section{RESULTS AND INTERPRETATION}

\section{TEXTURAL FEATURES}

Results of graphic methods (Folk and Ward, 1957) from sieve analysis are presented in Appendix $1^{*}$. The mean grainsize of the sandstones ranges from $0.01 \varnothing$ (coarse-grained) to 
$1.93 \varnothing$ (medium-grained). The standard deviation values of the sandstones vary from 0.73 to $1.09 \varnothing$, suggesting that the sand grains are moderately to poorly sorted (Appendix 1). Ten out of the fifteen samples have positive skewness, while the graphic kurtosis ranges from $0.50 \varnothing$ (very platykurtic) to $1.49 \varnothing$ (leptokurtic).

\section{PETROGRAPHY}

Petrographic analyses revealed that the Ajali Sandstone samples are moderately well-sorted. The framework grains of the sandstone is dominantly composed of sub-rounded to sub-angular monocrystalline $(\mathrm{Qm})$ and polycrystalline $(\mathrm{Qp})$ quartz and sub-ordinate amounts of feldspars, heavy minerals (rutile, zircon and tourmaline) and lithic fragments (Table 2 and Fig. 6). Quartz is the most abundant framework grain in the sandstones, constituting on average $95 \%$ of rock volume. According to Folk (1968) and Osae et al. (2006), detrital sandstones can be classified by their mineralogical compositions and matrix content. On the basis of their mineralogical compositions, the Ajali Sandstone samples are classified as quartz arenites (Fig. 7). The recalculated mineralogical maturity index (MMI) values of 0.93 to 0.99 suggest recycled and reworked parent materials for the Ajali Sandstone (Table 2).
Fedo et al. (1995) demonstrated that diagenetic processes are known to modify the geochemical composition of sedimentary rocks. Petrographic observations revealed that most of the sandstone samples contain minor amount of fine-grained quartz cement (on average $0.9 \%$; Table 2). The samples are dominated by framework grains (detritus) with little matrix. In most of the samples, low concentration of matrix (on average $2.3 \%$ ) were observed (Table 2). Among quartz grains, Qp (64.3 vol\%) is dominant over $\mathrm{Qm}$ (28.7 vol\%) and most $\mathrm{Qp}$ show straight to undulose extinction. $\mathrm{Qp}$ are angular to sub-angular while the $\mathrm{Qm}$ are rounded to sub-rounded. The Qp show 2 to 3 crystals and the contacts between crystals are sutured. Qp crystals do not show preferred orientation and they generally lack inclusion. Qm crystals generally lack inclusions and they show straight to slightly undulose extinction. These characteristic features of the $\mathrm{Qp}$ and Qm suggests a plutonic source for the quartz grains. Feldspar (F) grains are sub-angular and are comparatively less abundant $(2 \%)$ with dominant K-feldspar. The assemblage of heavy minerals is dominated by relatively stable heavy minerals such as rutile, zircon and tourmaline. All sandstone samples contain minor amounts of lithic fragments (on average 3\%). A plot of the mineralogical composition of the sandstone samples on the QFL diagram (Fig. 8) shows that all sandstone samples plot within the field of craton interior sources. This suggests that the Ajali Sandstone was derived from crystalline basement source rocks (Dickinson and Suczek, 1979; Dickinson et al., 1983).

Modal analysis results of the Ajali Sandstone

\begin{tabular}{|c|c|c|c|c|c|c|c|c|c|c|c|}
\hline \multirow{2}{*}{$\underset{\text { no }}{\text { Sample }}$} & \multirow{2}{*}{ Lithology } & \multicolumn{2}{|c|}{ Qt } & \multirow{2}{*}{$\mathrm{F}$} & \multirow{2}{*}{$\mathrm{Rf}$} & \multirow{2}{*}{$M$} & \multirow{2}{*}{ C } & \multicolumn{3}{|c|}{ [\%] } & \multirow{2}{*}{ MMI } \\
\hline & & $Q p$ & $\mathrm{Qm}$ & & & & & $Q$ & $\mathrm{~F}$ & $\mathrm{Rf}$ & \\
\hline AN1 & $\begin{array}{l}\text { fine-grained } \\
\text { sandstone }\end{array}$ & 64 & 31 & 1 & 2 & 1.6 & 0.4 & 96.9 & 1.0 & 2.0 & 0.97 \\
\hline AN2 & $\begin{array}{l}\text { fine-grained } \\
\text { sandstone }\end{array}$ & 66 & 26 & 2 & 3 & 2.4 & 0.6 & 94.8 & 2.1 & 3.1 & 0.95 \\
\hline AN3 & $\begin{array}{l}\text { coarse-grained } \\
\text { sandstone }\end{array}$ & 69 & 27 & 1 & 1 & 1.5 & 0.5 & 98.0 & 1.0 & 1.0 & 0.98 \\
\hline AN4 & $\begin{array}{l}\text { coarse-grained } \\
\text { sandstone }\end{array}$ & 79 & 15 & 2 & 2 & 1.7 & 0.3 & 95.9 & 2.0 & 2.0 & 0.96 \\
\hline AN5 & $\begin{array}{l}\text { medium-grained } \\
\text { sandstone }\end{array}$ & 64 & 28 & 1 & 3 & 3.1 & 0.9 & 95.8 & 1.0 & 3.1 & 0.96 \\
\hline AN6 & $\begin{array}{l}\text { fine-grained } \\
\text { sandstone }\end{array}$ & 63 & 27 & 3 & 2 & 3.8 & 1.2 & 94.7 & 3.2 & 2.1 & 0.95 \\
\hline AN7 & $\begin{array}{l}\text { coarse-grained } \\
\text { sandstone }\end{array}$ & 58 & 40 & - & 1 & 0.7 & 0.3 & 99.0 & 0.0 & 1.0 & 0.99 \\
\hline AY1 & $\begin{array}{l}\text { coarse-grained } \\
\text { sandstone }\end{array}$ & 53 & 37 & 1 & 3 & 4.3 & 1.7 & 95.7 & 1.1 & 3.2 & 0.96 \\
\hline AY2 & $\begin{array}{l}\text { medium-grained } \\
\text { sandstone }\end{array}$ & 70 & 24 & 1 & 2 & 2.1 & 0.9 & 96.9 & 1.0 & 2.1 & 0.97 \\
\hline AY3 & $\begin{array}{l}\text { fine-grained } \\
\text { sandstone }\end{array}$ & 62 & 36 & - & 1 & 0.7 & 0.3 & 99.0 & 0.0 & 1.0 & 0.99 \\
\hline BT1 & $\begin{array}{l}\text { coarse-grained } \\
\text { sandstone }\end{array}$ & 62 & 28 & 2 & 3 & 3.9 & 1.1 & 94.7 & 2.1 & 3.2 & 0.95 \\
\hline BT2 & $\begin{array}{l}\text { medium-grained } \\
\text { sandstone }\end{array}$ & 56 & 34 & 3 & 4 & 2.0 & 1.0 & 92.8 & 3.1 & 4.1 & 0.93 \\
\hline DI1 & $\begin{array}{l}\text { medium-grained } \\
\text { sandstone }\end{array}$ & 66 & 26 & 2 & 2 & 2.1 & 1.9 & 95.8 & 2.1 & 2.1 & 0.96 \\
\hline DO1 & $\begin{array}{l}\text { coarse-grained } \\
\text { sandstone }\end{array}$ & 67 & 25 & 3 & 2 & 1.8 & 1.2 & 94.8 & 3.1 & 2.1 & 0.95 \\
\hline DO2 & $\begin{array}{l}\text { coarse-grained } \\
\text { sandstone }\end{array}$ & 66 & 26 & 2 & 2 & 3.0 & 1.0 & 95.8 & 2.1 & 2.1 & 0.96 \\
\hline
\end{tabular}

Qp - polycrystalline quartz, Qm - monocrystalline quartz, Qt - total quartz, F - feldspar, Rf rock fragments, $\mathrm{M}$ - matrix, $\mathrm{C}$ - cement, $\mathrm{MMl}$ - mineralogical maturity index [Qt/[(Qt + F + Rf)] 

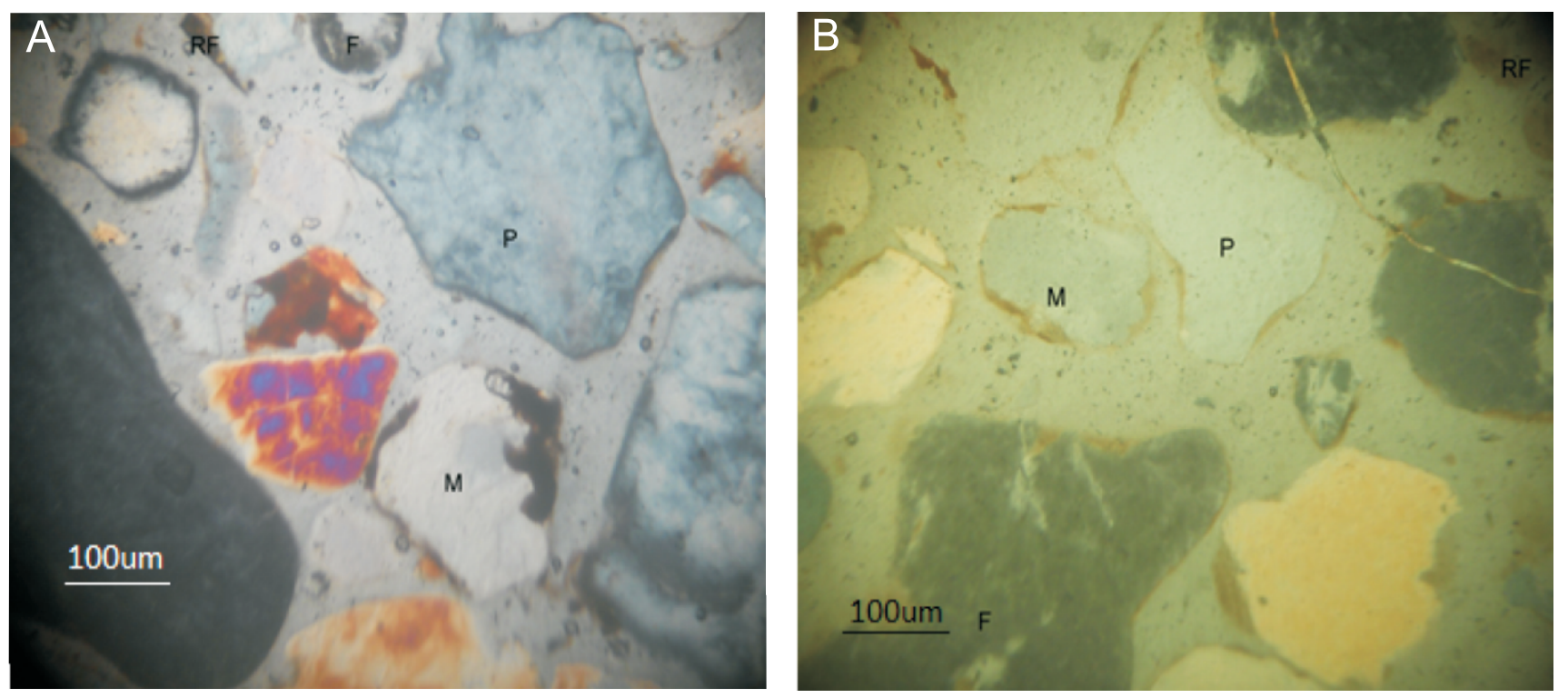

Fig. $6 \mathrm{~A}, \mathrm{~B}$ - thin section microphotographs showing mineralogical composition in quartz arenite of the Ajali Sandstone (crossed polars)

$\mathrm{M}$ - monocrystalline quartz, $\mathrm{P}$ - polycrystalline quartz, $\mathrm{F}$ - feldspars, RF - rock fragments

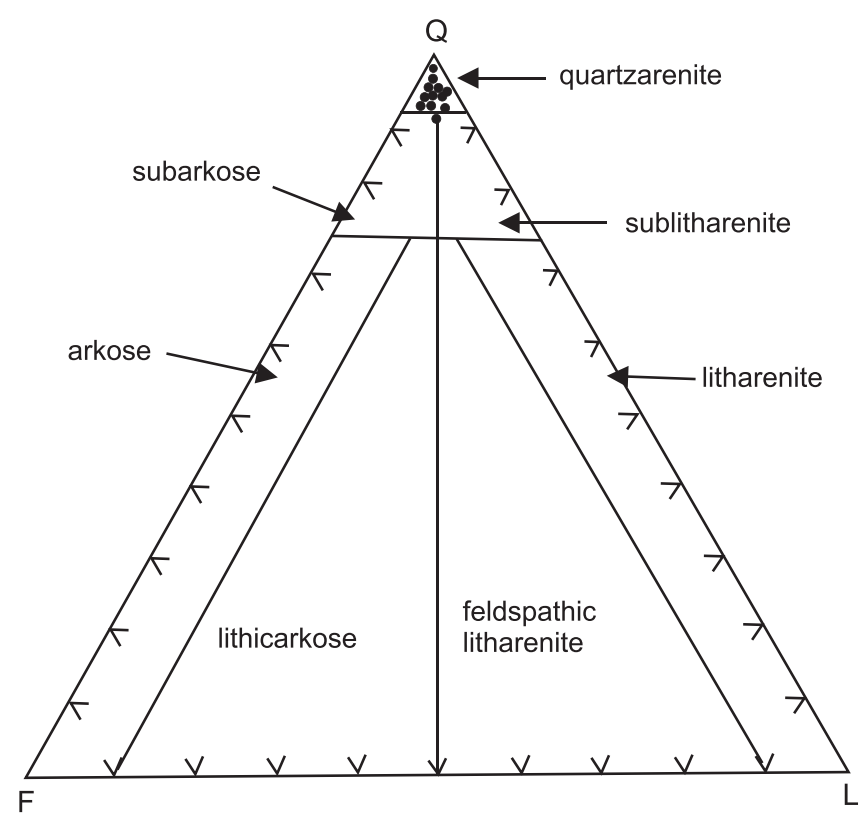

Fig. 7. QFL ternary diagram (Folk, 1968) showing compositional/fields of Ajali Sandstone

\section{GEOCHEMISTRY}

Analytical data of the major and trace elements for the quartz arenites and mudstones in the Ajali Sandstone samples are listed in Appendixes 1 and 2. The descriptive statistics of major and trace element contents of quartz arenites in the Ajali Sandstone samples are presented in Tables 3 and 4. The Ajali Sandstone is relatively depleted in most major and trace elements and enriched in $\mathrm{SiO}_{2}$, suggesting a high degree of weathering and reworking that probably removed ferromag-

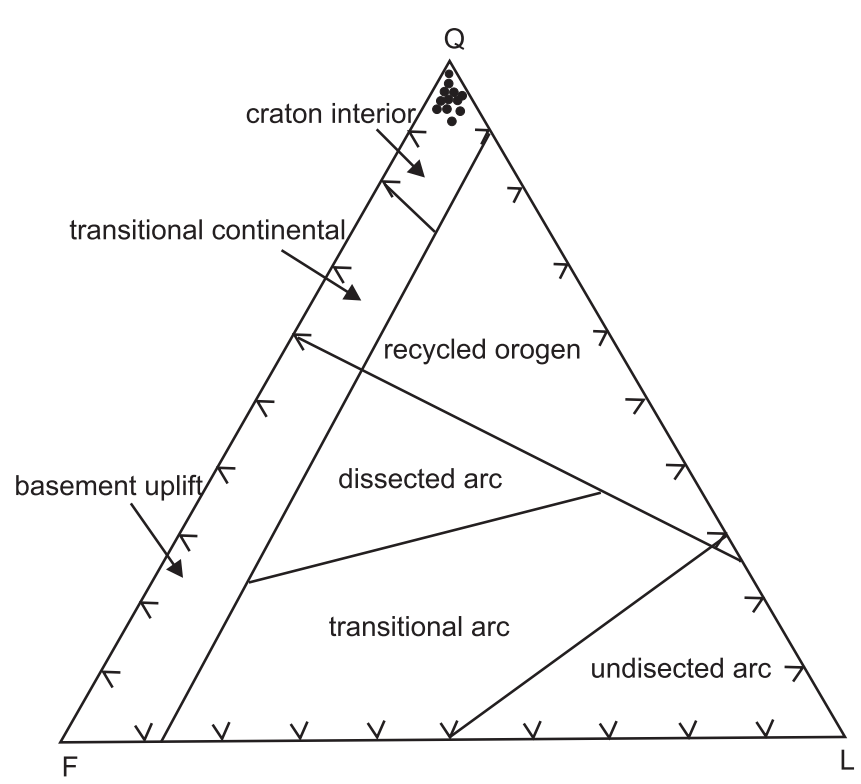

Fig. 8. QFL ternary diagram (Dickinson and Suczek, 1979; Dickinson et al., 1983) showing tectonic fields for the Ajali Sandstone

nesian minerals and feldspars (Getaneh, 2002). The average $\mathrm{Na}_{2} \mathrm{O}$ content for the Ajali Sandstone is $0.04 \%$. This depletion of $\mathrm{Na}_{2} \mathrm{O}(<1 \%)$ is reflected in the relatively smaller amount of $\mathrm{Na}$-rich plagioclase, as shown by the petrographical data. This result is consistent with those given by Armstrong-Altrin et al. (2004) and Osae et al. (2006). However, two mudstone samples (BT3 and DE1) have $\mathrm{SiO}_{2}$ and $\mathrm{Al}_{2} \mathrm{O}_{3}$ values of $49.1 \%$ and $74.5 \%$, and $30.3 \%$ and $16.2 \%$, respectively (Appendix 1). The high $\mathrm{Al}_{2} \mathrm{O}_{3}$ content reflects their protolithic nature. The most abundant trace elements in the Ajali Sandstone samples are $\mathrm{Zr}$ (mean of 120 ppm), Mn (72 ppm), Cr (21 ppm), Zn (13 ppm) and $\mathrm{Ba}(13 \mathrm{ppm})$. However, these concentration values are 
generally lower than the average upper continental crust (UCC) values (Armstrong-Altrin et al., 2004).

Using the geochemical classification diagram of Herron (1988), the Ajali Sandstone samples are classified as quartz arenites, except for two mudstone samples that fall in the shale and Fe-shale fields, respectively (Fig. 9).

\section{STATISTICAL TREATMENT}

The results obtained were subjected to statistical analysis to characterize the geochemistry of major and trace elements ( $\mathrm{Ta}-$ bles 3 and 4).

The correlation coefficients between major elements are listed in Appendix 3. There is a strong negative correlation between $\mathrm{Al}_{2} \mathrm{O}, \mathrm{Fe}_{2} \mathrm{O}_{3}, \mathrm{MgO}, \mathrm{K}_{2} \mathrm{O}, \mathrm{TiO}_{2}, \mathrm{P}_{2} \mathrm{O}_{5}$ and $\mathrm{LOI}$ with $\mathrm{SiO}_{2}$, reflecting the mineralogical maturity of the sediments. $\mathrm{Al}_{2} \mathrm{O}$ correlates well with $\mathrm{Fe}_{2} \mathrm{O}_{3}, \mathrm{MgO}, \mathrm{K}_{2} \mathrm{O}, \mathrm{TiO}_{2}, \mathrm{P}_{2} \mathrm{O}_{5}$, which implies a terrigenous origin for the sediment. Alumina, $\mathrm{SiO}_{2}$ and $\mathrm{K}_{2} \mathrm{O}$ exist in the form of silicate and/or aluminosilicate, whereas $\mathrm{TiO}_{2}$ and $\mathrm{Fe}_{2} \mathrm{O}_{3}$ are in the form of oxides. The modal composition of framework (MMI; that is the ratio of quartz to quartz + feldspar + rock fragments, Bhatia and Crook, 1986), matrix and cement were also correlated with major and trace elements. There is a positive correlation between $\mathrm{MMI}$ and $\mathrm{SiO}_{2}(r=0.65)$, and a negative correlation with $\mathrm{Al}_{2} \mathrm{O}_{3}$ and $\mathrm{LOI}(r=-0.71$ and $r=$ -0.61 ), respectively, indicating the mineralogical maturity of the sandstones. Cement correlates well with $\mathrm{K}_{2} \mathrm{O}(r=0.74) ; \mathrm{Fe}_{2} \mathrm{O}_{3}$ $(r=0.61)$ and $\mathrm{MnO}(r=0.60)$. There is no correlation of matrix with the major elements except $\mathrm{Na}_{2} \mathrm{O}(r=0.63)$. These interpretations suggest that the chemical compositions are related to the petrographic modal data.

Factor analysis was also employed to reveal any association of chemical elements and indeed the most likely underlying processes that have influenced such processes. The rotated factor matrix is presented in Table 5. A 3-factor model was adopted, which covers $94.4 \%$ of the total variance. The first factor provides strong positive loadings for $\mathrm{Al}_{2} \mathrm{O}, \mathrm{MgO}, \mathrm{K}_{2} \mathrm{O}, \mathrm{TiO}_{2}$, $\mathrm{P}_{2} \mathrm{O}_{5}$ and $\mathrm{LOI}$, and a negative loading for $\mathrm{SiO}_{2}$, accounting for $61.64 \%$ of the total data variance, while factor 2 (with high loadings of $\mathrm{Na}_{2} \mathrm{O}$ and $\mathrm{CaO}$ ) accounts for $18.21 \%$ of the total data variance. Factor 3 (with high loadings of $\mathrm{Fe}_{2} \mathrm{O}_{3}$ and $\mathrm{MnO}$ ) accounts for $14.5 \%$ of the total data variance. The loadings in factor 1 reflected elements that are associated mainly with clay minerals which constitutes the matrix. Factor 2 displays the

Table 3

Descriptive statistics of major oxides of quartz arenites in the Ajali Sandstone for 13 samples

\begin{tabular}{|l|c|c|c|c|}
\hline $\begin{array}{c}\text { Element } \\
(\mathrm{N}=13)\end{array}$ & Minimum & Maximum & Mean & $\begin{array}{c}\text { Standard } \\
\text { Deviation }\end{array}$ \\
\hline \multicolumn{5}{|c|}{$[\%]$} \\
\hline $\mathrm{SiO}_{2}$ & 96.74 & 100.30 & 98.57 & 1.23 \\
\hline $\mathrm{Al}_{2} \mathrm{O}_{3}$ & 0.14 & 2.02 & 0.66 & 0.66 \\
\hline $\mathrm{Fe}_{2} \mathrm{O}_{3}$ total & 0.29 & 1.20 & 0.87 & 0.30 \\
\hline $\mathrm{MnO}$ & 0.0009 & 0.01 & 0.01 & 0.003 \\
\hline $\mathrm{MgO}$ & 0.009 & 0.01 & 0.01 & 0.0003 \\
\hline $\mathrm{CaO}$ & 0.01 & 0.02 & 0.02 & 0.005 \\
\hline $\mathrm{Na}_{2} \mathrm{O}$ & 0.02 & 0.06 & 0.04 & 0.01 \\
\hline $\mathrm{K}_{2} \mathrm{O}$ & 0.009 & 0.03 & 0.02 & 0.01 \\
\hline $\mathrm{TiO}_{2}$ & 0.046 & 0.32 & 0.15 & 0.07 \\
\hline $\mathrm{P}_{2} \mathrm{O}_{5}$ & 0.009 & 0.02 & 0.01 & 0.003 \\
\hline $\mathrm{LOI}$ & -0.13 & 0.80 & 0.14 & 0.30 \\
\hline
\end{tabular}

highest loadings with $\mathrm{Na}_{2} \mathrm{O}$ and $\mathrm{CaO}$, which suggests a measure of terrigenous input, mainly in the form of calcic and sodic plagioclases. The high positive loading of $\mathrm{Fe}_{2} \mathrm{O}_{3}$ and $\mathrm{MnO}$ in

Table 4

Descriptive statistics of trace elements of quartz arenites in the Ajali Sandstone for 13 samples

\begin{tabular}{|l|c|c|c|c|}
\hline $\begin{array}{l}\text { Element } \\
(\mathrm{N}=13)\end{array}$ & Minimum & Maximum & Mean & $\begin{array}{c}\text { Standard } \\
\text { Deviation }\end{array}$ \\
\hline \multicolumn{5}{|c|}{$[\mathrm{ppm}]$} \\
\hline $\mathrm{Co}$ & 0.99 & 1.00 & 0.99 & 0.004 \\
\hline $\mathrm{Cr}$ & 6.00 & 46.00 & 20.77 & 12.02 \\
\hline $\mathrm{Cu}$ & 2.00 & 27.00 & 8.23 & 7.55 \\
\hline $\mathrm{Ga}$ & 0.99 & 3.00 & 1.46 & 0.78 \\
\hline $\mathrm{Hg}$ & 0.99 & 3.00 & 1.15 & 0.56 \\
\hline $\mathrm{Li}$ & 1.00 & 3.00 & 2.31 & 0.63 \\
\hline $\mathrm{Mn}$ & 37.00 & 113.00 & 71.85 & 20.74 \\
\hline $\mathrm{Mo}$ & 0.99 & 3.00 & 1.53 & 0.88 \\
\hline $\mathrm{Ni}$ & 0.99 & 4.00 & 3.23 & 1.09 \\
\hline $\mathrm{Pb}$ & 2.99 & 5.00 & 3.77 & 0.84 \\
\hline $\mathrm{Te}$ & 1.99 & 3.00 & 2.07 & 0.28 \\
\hline $\mathrm{Zn}$ & 2.00 & 42.00 & 13.15 & 12.87 \\
\hline $\mathrm{Ba}$ & 11.00 & 17.00 & 13.23 & 2.01 \\
\hline $\mathrm{Sr}$ & 5.00 & 10.00 & 6.54 & 1.56 \\
\hline $\mathrm{Y}$ & 0.00 & 4.00 & 1.92 & 0.95 \\
\hline $\mathrm{Sc}$ & 0.99 & 2.00 & 1.07 & 0.28 \\
\hline $\mathrm{Zr}$ & 67.00 & 313.00 & 119.85 & 63.25 \\
\hline $\mathrm{Be}$ & 0.99 & 0.99 & 0.99 & 0.00 \\
\hline $\mathrm{V}$ & 4.99 & 12.00 & 8.15 & 2.16 \\
\hline
\end{tabular}

Table 5

Varimax rotated factor loadings of 10 major elements and LOI on three significant components explaining $94.35 \%$ of the total variance for 15 Ajali Sandstone samples

\begin{tabular}{|l|c|c|c|}
\hline \multicolumn{1}{|c|}{ Variable } & Factor 1 & Factor 2 & Factor 3 \\
\hline $\mathrm{SiO}_{2}$ & -0.99 & -0.09 & -0.13 \\
\hline $\mathrm{Al}_{2} \mathrm{O}_{3}$ & 0.99 & 0.13 & 0.10 \\
\hline $\mathrm{Fe}_{2} \mathrm{O}_{3}$ total & 0.56 & -0.03 & 0.80 \\
\hline $\mathrm{MnO}$ & -0.14 & 0.39 & 0.90 \\
\hline $\mathrm{MgO}$ & 0.92 & 0.36 & 0.03 \\
\hline $\mathrm{CaO}$ & 0.32 & 0.79 & 0.30 \\
\hline $\mathrm{Na}_{2} \mathrm{O}$ & 0.01 & 0.90 & 0.07 \\
\hline $\mathrm{K}_{2} \mathrm{O}$ & 0.82 & 0.50 & 0.01 \\
\hline $\mathrm{TiO}_{2}$ & 0.98 & 0.09 & 0.11 \\
\hline $\mathrm{P}_{2} \mathrm{O}_{5}$ & 0.98 & -0.06 & 0.13 \\
\hline $\mathrm{LOI}$ & 0.99 & 0.11 & 0.08 \\
\hline Eigenvalues & 6.781 & 2.00 & 1.59 \\
\hline$\%$ of variance & 61.64 & 18.21 & 14.50 \\
\hline Cumulative \% & 61.64 & 79.85 & 94.35 \\
\hline
\end{tabular}


factor 3 suggests the possibility of hydrogeneous ferro-manganese formation during sedimentation.

The correlation coefficients between trace elements of the Ajali Sandstone are listed in Appendix 4. The great majority of trace elements show strong positive correlation coefficients with each other (Appendix 4). This suggests a common detrital source for the bulk of these elements. Factor analysis (FA) was applied to the correlation matrix. The initial application of FA produced overlap in factors for Mo. The rotated factor matrix is presented in Table 6. A four-factor model covering $93.8 \%$ of the total data variance was adopted (Table 6). Only variables with loading values greater than 0.50 were considered significant members of a particular factor. Factor 1 explains $66.1 \%$ of the total variance and consists of high loading values of $\mathrm{Co}, \mathrm{Cr}, \mathrm{Ga}, \mathrm{Ni}, \mathrm{Pb}, \mathrm{Te}, \mathrm{Zn}, \mathrm{Ba}, \mathrm{Sr}, \mathrm{Y}, \mathrm{Sc}, \mathrm{Zr}$, Be and $V$. The loading in factor 1 is indicative of elements showing affinity for both acidic and mafic source rocks. Factor 2 explains $10.3 \%$ of the variance in the data set. The major component of this factor is $\mathrm{Li}$, which reflects the clay component of the sediment. Factor 3 explains $9.7 \%$ of the total variance and consists of $\mathrm{Cu}$ and $\mathrm{Mn}$ which may suggest the activities of hydrogenous bacteria enrichment of $\mathrm{Cu}, \mathrm{Fe}$ and $\mathrm{Mn}$ in the sediment. This is also supported by the positive correlation of cement with $\mathrm{Cu}(r=0.83)$ and $\mathrm{Mn}(r=0.64)$ as well as the negative correlation of $\mathrm{MMI}$ with estimated values of $\mathrm{Cu}$ and $\mathrm{Mn}$ values, respectively $(r=-0.88$ and $r=-0.61)$.

\section{SOURCE-AREA WEATHERING}

The extent of chemical alteration in sedimentary rocks during weathering can be evaluated by examining the relationships

Table 6

Varimax rotated factor loadings of 20 trace elements on four significant components explaining $93.8 \%$ of the total variance for 15 Ajali Sandstone samples

\begin{tabular}{|l|c|c|c|c|}
\hline \multicolumn{1}{|c|}{ Variable } & Factor 1 & Factor 2 & Factor 3 & Factor 4 \\
\hline $\mathrm{Co}$ & 0.946 & 0.296 & -0.049 & 0.119 \\
\hline $\mathrm{Cr}$ & 0.954 & -0.121 & 0.000 & -0.213 \\
\hline $\mathrm{Cu}$ & 0.081 & 0.530 & 0.782 & -0.026 \\
\hline $\mathrm{Ga}$ & 0.971 & 0.184 & -0.040 & 0.140 \\
\hline $\mathrm{Hg}$ & 0.279 & -0.266 & -0.093 & 0.646 \\
\hline $\mathrm{Li}$ & 0.336 & 0.840 & 0.154 & 0.071 \\
\hline $\mathrm{Mn}$ & -0.230 & -0.069 & 0.937 & -0.022 \\
\hline $\mathrm{Mo}$ & -0.044 & -0.316 & -0.079 & -0.855 \\
\hline $\mathrm{Ni}$ & 0.978 & 0.121 & 0.068 & 0.120 \\
\hline $\mathrm{Pb}$ & 0.945 & 0.302 & -0.021 & 0.103 \\
\hline $\mathrm{Te}$ & 0.925 & -0.284 & -0.019 & 0.203 \\
\hline $\mathrm{Ba}$ & 0.915 & 0.382 & -0.059 & 0.102 \\
\hline $\mathrm{Zn}$ & 0.744 & 0.065 & 0.536 & 0.166 \\
\hline $\mathrm{Sr}$ & 0.985 & 0.082 & -0.036 & 0.137 \\
\hline $\mathrm{Y}$ & 0.956 & 0.256 & -0.037 & 0.132 \\
\hline $\mathrm{Sc}$ & 0.960 & 0.239 & -0.046 & 0.135 \\
\hline $\mathrm{Zr}$ & 0.910 & 0.318 & -0.070 & 0.158 \\
\hline $\mathrm{Be}$ & 0.931 & -0.264 & -0.025 & 0.191 \\
\hline $\mathrm{V}$ & 0.980 & 0.130 & -0.044 & 0.141 \\
\hline Eigenvalues & 12.56 & 1.95 & 1.84 & 1.47 \\
\hline$\%$ of variance & 66.09 & 10.28 & 9.68 & 7.76 \\
\hline $\mathrm{Cumulative} \%$ & 66.09 & 76.36 & 86.05 & 93.80 \\
\hline
\end{tabular}

among alkali and alkaline earth elements (Nesbitt and Young, 1982). Nesbitt et al. (1980) observed that during weathering processes, calcium, sodium and potassium are the main elements leached and carried away by groundwater. A good measure of the degree of chemical weathering can be obtained by calculation of chemical index of weathering (CIW; Harnois, 1988), chemical index of alteration (CIA; Nesbitt and Young, 1982) and plagioclase index of alteration (PIA; Fedo et al., 1995). High CIW, CIA and PIA values (75-100\%) indicate intensive weathering in the source area whereas low values $(60 \%$ or less) indicate low weathering in source area.

The CIW, CIA and PIA values for the Ajali Sandstone vary from 77.1 to $99.8 \%, 74.1$ to $99.2 \%$ and 76.6 to $99.4 \%$, respectively (Appendix 1). The high CIW, CIA and PIA values suggest high degree of chemical weathering in the source area from adjacent Cameroon basement complex and Oban Massif (Hoque and Ezepue, 1977; Tijani et al., 2010).

\section{IMPLICATIONS}

\section{PROVENANCE AND TECTONIC SETTING}

The use of quantitative triangular diagrams based on plots of quartz $(\mathrm{Q})$, feldspar $(F)$ and rock fragments $(L)$ can serve as a powerful indicator of tectonic setting of the source area. Dickinson and Suczek (1979) and Dickinson et al. (1983) established a ternary diagram relating sandstone compositions to different provenance types such as undissected arc, transitional arc, dissected arc, recycled orogen, basement uplift, transitional continental and craton interior. Others, including Bhatia (1983), and Roser and Korsch (1986), Getaneh (2002), have used graphical schemes showing relative elemental abundance to define the tectonic setting of provenances. On a QFL diagram of Dickinson and Suczek (1979) the Ajali Sandstones plot entirely in the craton interior field (Fig. 8). According to Dickinson and Suczek (1979) and Dickinson et al. (1983), sandstones plotting within the craton interior field are mature sandstones derived from igneous source rocks. On the $\mathrm{K}_{2} \mathrm{O} / \mathrm{Na}_{2} \mathrm{O}$ versus $\mathrm{SiO}_{2}$ discrimination diagram (Fig. 10) of Roser and Korsch (1986) the analysed samples plot entirely in the passive margin field. This result is consistent with the classification of

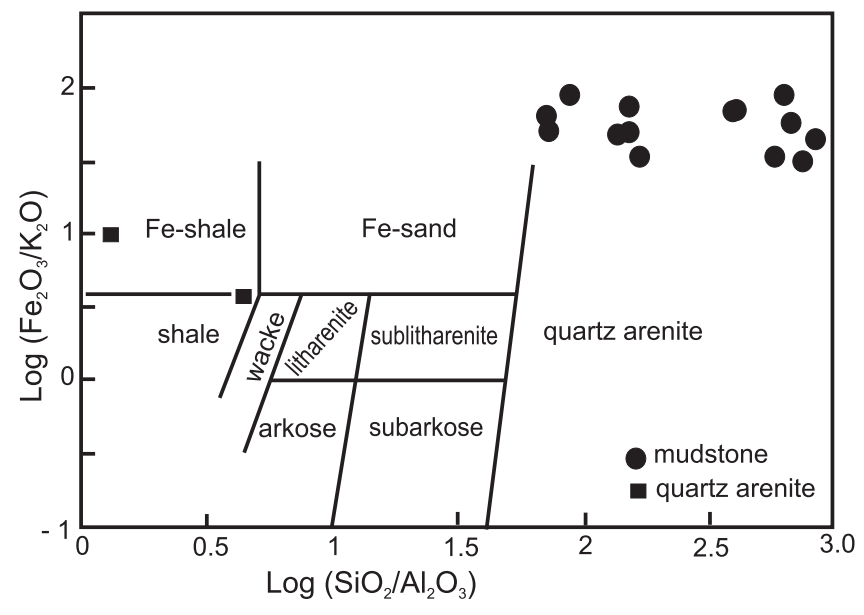

Fig. 9. Chemical classification of the Ajali Sandstone (fields after Herron, 1988) 
Roser and Korsch (1986) and Osae et al. (2006), which linked quartz-rich sediments to the passive continental margin derived from plate interiors or stable continental areas.

Several authors (Ronov et al., 1974; Bhatia, 1983; Dickinson et al., 1983; Bhatia and Crook, 1986; Roser and Korsch, 1986, 1988) have used the geochemical compositions (major and trace elements) of sandstones to infer the provenance of source materials. Hayashi et al. (1997) suggested that $\mathrm{Al}_{2} \mathrm{O}_{3} / \mathrm{TiO}_{2}$ ratios of 3 to 8 are indicative of mafic igneous rocks, 8 to 21 for intermediate igneous rocks, and 21 to 70 for felsic igneous rocks. The $\mathrm{Al}_{2} \mathrm{O}_{3} / \mathrm{TiO}_{2}$ ratios of quartz arenites and mudstones in the Ajali Sandstone range from 1.39 to 12.48 and 9.59 to 10.88 , respectively. On the Roser and Korsch (1988) discrimination diagram (Fig. 10) for sedimentary provenance, majority of the samples plot within the quartzose sedimentary provenance with one sample lying within the felsic igneous provenance, supporting the interpre-

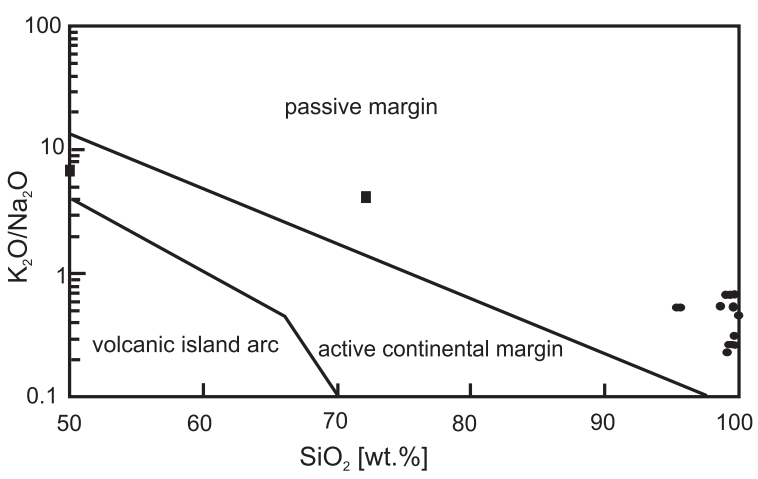

Fig. 10. Discrimination diagram for sedimentary tectonic setting (after Roser and Korsch, 1986) for the Ajali Sandstone

For explanations see Figure 9

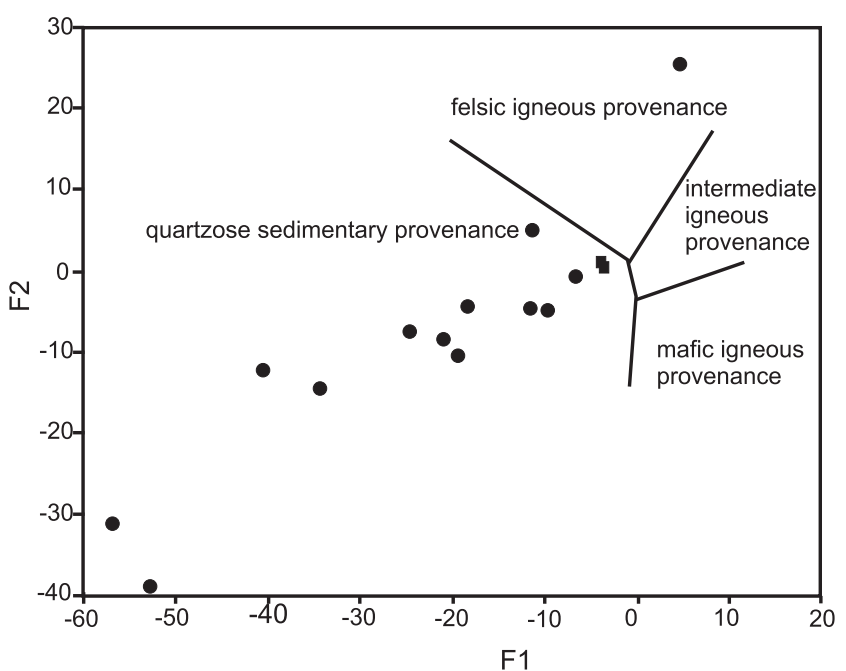

Fig. 11. Discrimination diagram for provenance signatures (after Roser and Korsch, 1988) of the Ajali Sandstone

$\mathrm{F} 1=30.638 \mathrm{TiO}_{2} / \mathrm{Al}_{2} \mathrm{O}_{3}-12.541 \mathrm{Fe}_{2} \mathrm{O}_{3}$ (total) $/ \mathrm{Al}_{2} \mathrm{O}_{3}+7.329$ $\mathrm{MgO} / \mathrm{Al}_{2} \mathrm{O}_{3}+12.031 \mathrm{Na}_{2} \mathrm{O} / \mathrm{Al}_{2} \mathrm{O}_{3}+35.402 \mathrm{~K}_{2} \mathrm{O} / \mathrm{Al}_{2} \mathrm{O}_{3}-6.382 ; \mathrm{F} 2=$ $56.5 \mathrm{TiO}_{2} / \mathrm{Al}_{2} \mathrm{O}_{3}-10.879 \mathrm{Fe}_{2} \mathrm{O}_{3}$ (total) $/ \mathrm{Al}_{2} \mathrm{O}_{3}+30.875 \mathrm{MgO} / \mathrm{Al}_{2} \mathrm{O}_{3}$ $-5.404 \mathrm{Na}_{2} \mathrm{O} / \mathrm{Al}_{2} \mathrm{O}_{3}+11.112 \mathrm{~K}_{2} \mathrm{O} / \mathrm{Al}_{2} \mathrm{O}_{3}-3.89$; for other explanations see Figure 9 tation that the sandstones were derived from a mixed provenance of granitic rocks and recycled sediments. Also, the high $\mathrm{CIA}$ and $\mathrm{CIW}$ values of the samples support the assertion that the recycled sediments were derived from the uplifted extrusive and sedimentary units of the adjacent Abakaliki Anticlinorium (Tijani et al., 2010), and the adjacent Cameroon Basement Complex and Oban Massif (Hoque and Ezepue, 1977). Furthermore, the high $\mathrm{Zr} / \mathrm{Sc}$ values $(68-313 \mathrm{ppm}$ ) of the quartz arenites in the Ajali Sandstones and low $\mathrm{Zr} / \mathrm{Sc}$ values (44-55 ppm) of the mudstone samples are similar to the values of sediments derived from felsic and mafic basement (Osae et al., 2006) of the adjacent basement complex.

Taylor and McLennan (1985) and Bhatia and Crook (1986) have showed that $\mathrm{Ta}$, Th, Co, Sc, $\mathrm{Zr}, \mathrm{Hf}, \mathrm{Nb}$ and rare earth element (REE) have low mobility during sedimentary processes. Trace elements such as $\mathrm{Co}, \mathrm{Sc}, \mathrm{Ni}$ and $\mathrm{Cr}$ are more concentrated in mafic than in felsic igneous rocks (Taylor and McLennan, 1985). Hence, ratios such as $\mathrm{Zr} / \mathrm{Cr}$, Ti/Zr, La/Co, $\mathrm{Th} / \mathrm{Co}, \mathrm{Cr} / \mathrm{Th}$ are considered to be good discriminators between mafic and felsic source rocks. The $\mathrm{Ti} / \mathrm{Zr}$ ratios of the quartz arenites and mudstone in the Ajali Sandstone samples range from 6.5 to 16.7 and 19.3 to 31.1 , respectively. This result is consistent with the values commonly recorded for felsic igneous rocks $(<20)$, unlike mafic igneous rocks that are characterized by higher values greater than 50 . Also, the $\mathrm{Zr} / \mathrm{Cr}$ ratios of 2.3 to 22.4 for the analysed samples are consistent with the value of greater than two for felsic igneous rocks, compared to less than one for the mafic type (Tijani et al., 2010). The high $\mathrm{Zr} / \mathrm{Cr}$ ratio can be attributed to possible reconcentration of zircon grains by hydraulic sorting during the sedimentary processes (Tijani et al., 2010).

The low concentrations of trace elements such as $\mathrm{Cr}, \mathrm{Ni}$, Sc, V, and Co in the quartz arenites of the Ajali Sandstone indicate that very minimal mafic rocks were exposed in the source area (Table 3). This result is in agreement with those given by Osae et al. (2006). According to Wrafter and Graham (1989) and Garver et al. (1996), high $\mathrm{Cr}$ and Ni contents ( $\mathrm{Cr}>150 \mathrm{ppm}$ and $\mathrm{Ni}>100 \mathrm{ppm}$ ) are indicative of ultramafic rocks in the source area, while low abundance indicates felsic provenance. The generally low $\mathrm{Cr}$ and $\mathrm{Ni}$ abundances (Table 4) in the quartz arenites of the Ajali Sandstone suggest a felsic provenance. Furthermore, high-field-strength elements (HFSE) such as $\mathrm{Zr}$, $\mathrm{Nb}, \mathrm{Hf}, \mathrm{Y}, \mathrm{Th}$, and $\mathrm{U}$ are enriched in felsic rather than mafic sources (Feng and Kerrich, 1990) and, as a consequence, reflect provenance compositions due to their immobile character (Taylor and McLennan, 1985). The relatively high concentration of $\mathrm{Zr}$ in the analysed samples suggests a contribution from a felsic source.

\section{CONCLUSIONS}

Petrographic analyses of the Ajali Sandstone show that the sandstones are mainly quartz arenites. Quartz is the most abundant framework grain in the sandstones, constituting on average $95 \%$ of rock volume. The sandstones are texturally immature as depicted by their sub-angular edges but mineralogically mature in terms of high percentage of quartz. Petrographic and geochemical studies suggests that the sediments of the Ajali Sandstone were derived from felsic igneous and recycled sedimentary source rocks, most likely the granitic complex of the Cameroon highlands and the Oban Massif.

The multivariate statistical techniques including factor analysis revealed that the chemistry of the sediment was influenced 
by the associated clay minerals that constitute the matrix, terrigenous input, sub-aqueous ferromanganese formation in the sediment, and the basement provenance. The inferred tectonic setting of the depositional basin suggests that the Ajali Sandstone was deposited on a passive margin.
Acknowledgements. The authors are thankful to Activation Laboratories, Ontario, Canada, for the chemical analyses of the entire samples. We also acknowledge the contributions, comments and suggestions of D.K. Asiedu, M.N. Tijani and the anonymous reviewers.

\section{REFERENCES}

Agagu, O.K., Fayose, E.A., Petters, S.W., 1985. Stratigraphy and sedimentation in the Senonian Anambra Basin of eastern Nigeria. Journal of Mining and Geology, 22: 25-36.

Akande, S.O., Ogunmoyero, I.B., Petersen, H.I., Nytoft, H.P., 2007. Source rock evaluation of coals from the Lower Maastrichtian Mamu Formation, SE Nigeria. Journal of Petroleum Geology, 30: 303-324.

Amajor, L.C., 1984. Sedimentary facies of the Ajali Sandstone (Upper Cretaceous), southern Benue Trough. Journal of Mining and Geology, 28: 7-17.

Armstrong-Altrin, J.S., Lee, Y.I., Verma, S.P., Ramasamy, S., 2004. Geochemistry of sandstones from the Upper Miocene Kudankulam Formation, southern India: implications for provenance, weathering, and tectonic setting. Journal of Sedimentary Research, 74: 285-297.

Banerjee, I., 1979. Quantitative analysis of stratigraphic sequences. Journal of Mining and Geology, 16: 111-118.

Benkhelil, J., 1989. The evolution of the Cretaceous Benue Trough, Nigeria. Journal of African Earth Sciences, 8: 251-282.

Bhatia, M.R., 1983. Plate tectonics and geochemical composition of sandstones. Journal of Geology, 91: 611-627.

Bhatia, M.R., Crook, A.W., 1986. Trace element characteristics of graywackes and tectonic setting discrimination of sedimentary basins. Contributions to Mineralogy and Petrology, 92: 181-193.

Burke, K.C., Dessauvagie, T.F.G., Whiteman, A.J., 1972. Geological History of the Benue Valley and Adjacent Areas (eds. T.F.J. Dessauvagie and A.J. Whiteman): 187-205. University of Ibadan, Nigeria.

Dickinson, W.R., 1970. Interpreting detrital modes of greywacke and arkose. Journal of Sedimentary Petrology, 40: 695-707.

Dickinson, W.R., Suczek, C.A., 1979. Plate tectonics and sandstone compositions. AAPG Bulletin, 63: 2164-2182.

Dickinson, W.R., Beard, L.S., Brakenridge, G.R., Erjavec, J.L., Ferguson, R.C., Inman, K.F., Knepp, R.A., Lindberg, F.A., Ryberg, P.T., 1983. Provenance of North American Phanerozoic sandstone in relation to tectonic setting. GSA Bulletin, 94: 222-235.

Fedo, C.M., Nesbitt, H.W., Young, G.M., 1995. Unraveling the effects of potassium metasomatism in sedimentary rocks and paleosols, with implications for weathering conditions and provenance. Geology, 23: 921-924.

Feng, R., Kerrich, R., 1990. Geochemistry of fine-grained clastic sediments in the Archean Abitibi greenstone belt, Canada: implications for provenance and tectonic setting. Geochimica et Cosmochimica Acta, 54: 1061-1081.

Folk, R.L., 1968. Petrology of Sedimentary Rocks. Hemphill's, Austin, Texas.

Folk, R.L., Ward, W., 1957. Brazos River bar, a study in significance of grain size parameters. Journal of Sedimentary Petrology, 27: $3-26$.

Garver, J.I., Royce, P.R., Smick, T.A., 1996. Chromium and nickel in shale of the Taconic Foreland: a case study for the prove- nance of fine-grained sediments with an ultramafic source. Journal of Sedimentary Research, 66: 100-106.

Gazzi, P., 1966. Le arenarie del flysch sopracretaceo dell' Appennino modenese; correlazioni con il flysch di Monghidoro. Mineralogica et Petrographica Acta, 12: 69-97.

Getaneh, W., 2002. Geochemistry provenance and depositional tectonic setting of the Adigrat Sandstone, northern Ethiopia. Journal of African Earth Sciences, 35: 185-198.

Harnois, L., 1988. The CIW Index: a new chemical index for weathering. Sedimentary Geology, 55: 319-322.

Hayashi, K., Fujisawa, H., Holland, H., Ohmoto, H., 1997. Geochemistry of $\sim 1.9$ Ga sedimentary rocks from northeastern Labrador, Canada. Geochimica et Cosmochimica Acta, 61: 4115-4137.

Herron, M.M., 1988. Geochemical classification of terrigenous sands and shales from core and log data. Journal of Sedimentary Petrology, 58: 820-829.

Hoque, M., 1977. Petrographic differentiation of tectonically controlled Cretaceous sedimentary cycles, southeastern Nigeria. Sedimentary Geology, 17: 235-245.

Hoque, M., Ezepue, M., 1977. Petrology and paleogeography of Ajali Sandstone. Journal of Mining and Geology, 14: 16-22.

Ladipo, K.O., 1986. Tidal shelf depositional model for the Ajali Sandstone, Anambra Basin, southeastern Nigeria. Journal of African Earth Sciences, 5: 177-185.

Ladipo, K.O., 1988. Paleogeography, sedimentation and tectonics of the Upper Cretaceous Anambra Basin, southeastern Nigeria. Journal of African Earth Sciences, 7: 865-871.

Murat, R.C., 1972. Stratigraphy and paleogeography of the Cretaceous and lower Tertiary in southern Nigeria. In: African Geology (eds. T.F.J. Dessauvagie and A.J. Whiteman): 251-266. University of Ibadan Press, Nigeria.

Nesbitt, H.W., Young, G.M., 1982. Early Proterozoic climates and plate motions inferred from major element chemistry of lutites. Nature, 299: 715-717.

Nesbitt, H.W., Markovics, G., Price, R.C., 1980. Chemical processes affecting alkalies and alkaline earths during continental weathering. Geochimica et Cosmochimica Acta, 44: 1659-1666.

Nwachukwu, S.O., 1972. The tectonic evolution of the southern portion of the Benue Trough, Nigeria. Geological Magazine, 109: $411-419$

Olade, M.A., 1975. Evolution of the Nigeria's Benue Trough (aulacogen): a tectonic model. Geological Magazine, 112: 575-583.

Osae, S., Asiedu, D.K., Banoeng-Yakubo, B., Koeberl, C., Dampare, S.B., 2006. Provenance and tectonic setting of Late Proterozoic Buem sandstones of southern Ghana: evidence from geochemistry and detrital modes. Journal of African Earth Sciences, 44: 85-96.

Reyment, R.A., 1965. Aspects of Geology of Nigeria. University of Ibadan Press.

Ronov, A.B., Balashov, Y.A., Girin, Y.P., Bratishko, R.K.H., Kazakov, G.A., 1974. Regularities of rare earth element distri- 
bution in the sedimentary shell and in the crust of the Earth. Sedimentology, 21: 171-193.

Roser, B.P., Korsch, R.J., 1986. Determination of tectonic setting of sandstone-mudstone suites using $\mathrm{SiO}_{2}$ content and $\mathrm{K}_{2} \mathrm{O} / \mathrm{Na}_{2} \mathrm{O}$ ratio. Journal of Geology, 94: 635-650.

Roser, B.P., Korsch, R.J., 1988. Provenance signatures of sandstone-mudstone suite determined using discriminant function analysis of major element data. Chemical Geology, 67: 119-139.

Short, K.C., Stauble, A.J., 1967. Outline of geology of Niger Delta. AAPG Bulletin, 51: 761-779.

Simpson, A., 1947. Geology of the Escarpment, North of Enugu. Annual Report of Geological Survey of Nigeria: 9-14.
Simpson, A., 1954. The Nigerian coal field: the geology of parts of Onitsha, Owerri, and Benue provinces. Geological Survey of Nigeria Bulletin, 24.

Tattam, C.M., 1944. A Review of Nigeria Stratigraphy. Report of Geological Survey of Nigeria: 22-47.

Taylor, S.R., McLennan, S., 1985. The Continental Crust: its Composition and Evolution. Blackwell, London.

Tijani, M.N., Nton, M.E., Kitagawa, R., 2010. Textural and geochemical characteristics of the Ajali Sandstone, Anambra Basin, SE Nigeria: implication for its provenance. Comptes Rendus Geoscience, 342: 136-150.

Wrafter, J.P., Graham, J.R., 1989. Ophiolitic detritus in the Ordovician sediments of south Mayo Ireland. Journal of the Geological Society, 146: 213-215. 